Received 1 April 2019; accepted 17 June 2019.

Available online 1 October 2019

\title{
Towards Great Streets: Sustainable Design Solutions
}

\author{
Rania El Messeidy \\ Lecturer, Department of Architecture, Faculty of Engineering, October University for Modern \\ Sciences and Arts (MSA) University, 6th of October, Cairo, Egypt \\ rhamdi@msa.eun.eg_rania_h2000@yahoo.com
}

\section{ABSTRACT}

Streetscape design is not only about an attractive visual image in the city, or an interesting walking trip while feeling shaded, secured, and comfort. Streetscape design plays a vital role in connecting and accessing communities' resources. When designed as sustainable; streets help to develop communities in terms of environmental, social, and economic aspects. In addition, sustainable streets protect and enhance the city's character and aesthetics. This research aims to highlight the importance of sustainability approach when designing a street whether it is a new street or a transformation of an existing one in order to be great. This paper is based on exploring the relationship between the basic principles of streetscape design and the sustainability framework comprising of its regular aspects: environmental, social, and economic. The paper highlights the intersection between the two main factors: 1. Streetscape design, 2 . Sustainability framework. The research proposes a matrix through its application on an international case study to reach the final matrix. The final proposed matrix will be applied on Al-Alfy' street in Cairo as a local case study. As conclusion the paper provides a checklist that may help developing sustainable design solutions for designing great streets.

\section{KEYWORDS}

Basic Streetscape Principles, Sustainability Framework, Great Streets.

\section{INTRODUCTION}

Streets have always been a vital component of urban environment. With all its physical elements, activities of pedestrian or travelers, visual aspects, streetscape and the buildings facades; streets play a great role in the community's life as well as affecting the inhabitant behavior. Many researches have dig deep in analyzing and studying how streets could be better in terms of streetscape, pedestrian requirements and the street's function itself. However, many of these works contributed in having a functional, walkable, safe and maybe green street, but not so many researches deal with the street's function as a community connector through a sustainable design solution.

Streets serve many purposes besides carrying vehicles, city sidewalks and pedestrians. These uses are bound up with circulation but are not identical with it and in their own right they are at least as basic as circulation to the proper workings of cities (Jacobs, J., 1961). 
A review of the literature on livable streets indicates that the degree of liveliness and form is influenced by many factors. The character of the street varies according to the purpose and function of the location, physical form and appearance, socioeconomic and cultural characteristics of the user as well as the inhabitant. This may affect the needs and perceptions of the users that might be different from other street users in other countries. The presence of people and activities on the street affect the livability of the city (Appleyard, 1981).

There is an important factor that can persuade people to use the street. Attraction or desirability is related to the qualities engaged with by the eyes, aesthetic values and entertainment quality. Users of all ages do not always simply choose the most obvious route to reach their destination; they are also influenced by how interesting or dull each route is (Gehl, 2000).

On this background, this paper provides an approach based on facts. The paper is based on the experience of transforming "South Grand Boulevard" St. Louis, to a "Great Street". What is meant here by "Great Street" is not only a functionally completed street that accomplished the principles of Jane Jacobs (1961), but a transformation of the street into a great community resource; where the residents and local leaders have been a parties to the decision-making process and the design process in order to reach sustainable design solutions in terms of environment, community, economics and arts. Thus the desired street design was a conclusion of solving problems, accessing opportunities, involving community and as well implementing sustainable streetscape practices. This paper will focus through the theoretical part on determining the streetscape basic principles and how could it be implemented, also on the sustainability framework and its essential aspects. The paper proposes here a matrix combining the two main factors: 1 . Streetscape Basic Principles, 2. Sustainability framework. Then the paper will proceed in the applied part by implementing the proposed matrix on an international case study in order to reach the final matrix. The final proposed matrix will be applied on Al-Alfy' street in Cairo as a local case study. Moreover, this paper concludes a sort of checklist based on the final matrix to help checking the achievement of sustainable design solutions when designing great streets.

\section{STREETSCAPE BASIC PRINCIPLLES}

According to "Urban Streetscape Design", a book released (2014); there are six basic principles if implemented; a high quality and responsive street is achieved (Song, S., 2014)

\subsection{Sustainable Streetscape Practices}

Sustainable streetscape design could be reached when implementing the following practices: storm water management, use of sustainable materials, efficient lighting, reduce urban heat islands. 
Storm water management could be done using best management practices such as: bioswales, previous paving, rain gardens, and rain barrels (Berland, A., 2017). Implementing techniques to manage storm water prevent flooding, sewer back-ups, and reduce the negative impacts of poor management of urbanization (O'Neill, S. J., 2016). Fig (1, 2).

Figures $(\mathbf{1}, \mathbf{2})$ Storm water management in Mint Plaza, San Francisco, USA

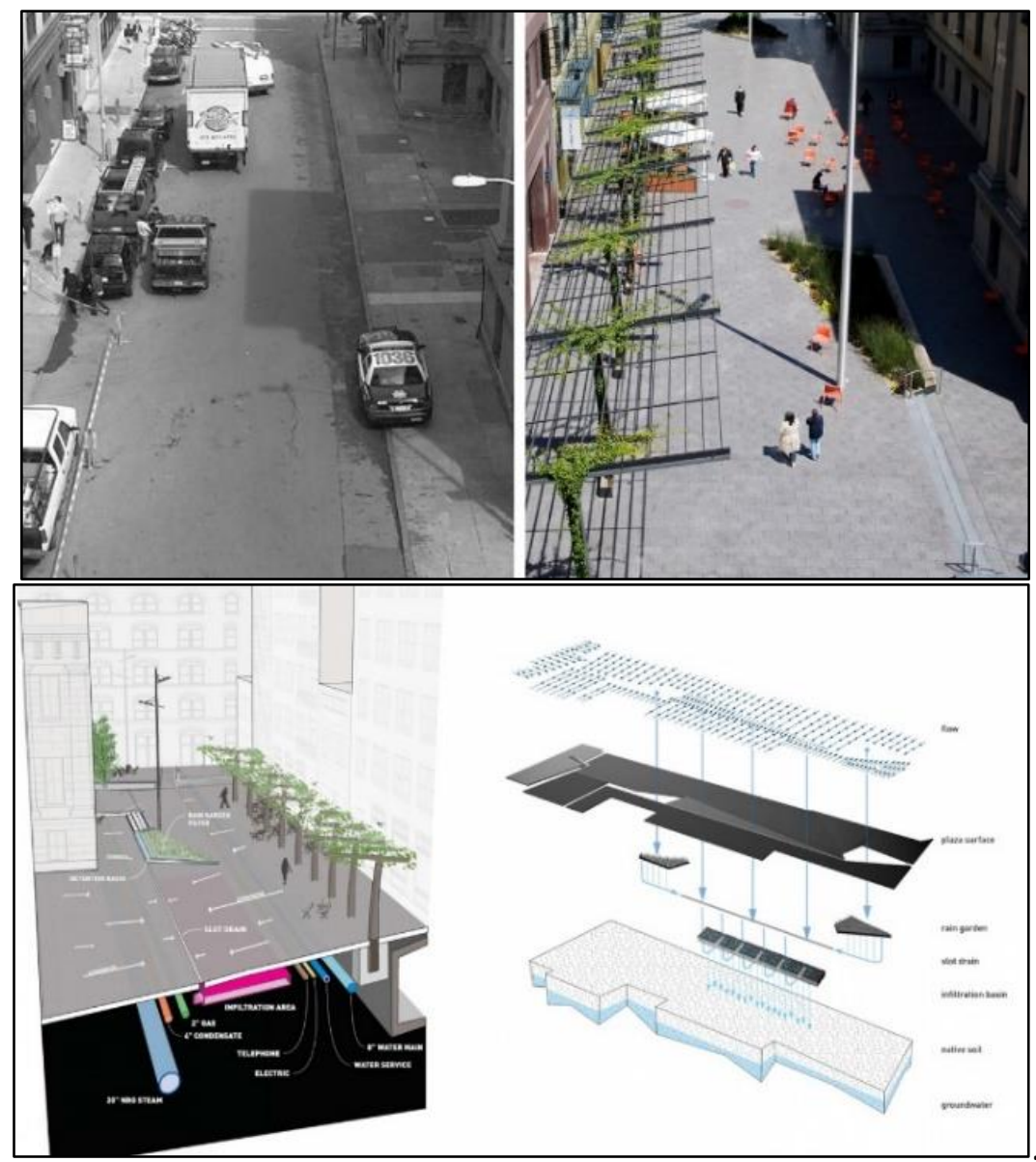

Source: Song, S., 2014

Use of sustainable materials provide the reduction of using energy, conservation of natural resources, also, using materials that are not toxic (Akadiri, P. O., 2012)

Open air lighting is significant in urban environment. Suitable lighting levels advance a sentiment of comfort and security and energize people on foot movement (Lindfield, M. Steinberg, F., 2012). Using lighting on buildings facades highlight it and enrich the district's character. The kinds of light source impact energy consumption and sustainability. Efficient light sources can accomplish identical lighting levels with lower energy consumption. For example, "high pressure sodium vapor lights are very efficient, but their orange-yellow light renders color poorly. Metal halide's white light, on the other hand, renders colors and surfaces more realistically (G. S. B. Ganandran, et al., 2014). Current studies indicate that human peripheral vision and visual acuity in urban settings is substantially better under white light than orange light". Fig $(3,4)$. 
Figure $(3,4)$ Use of Efficient lighting in Plaza Del Torico, Teruel, Spain

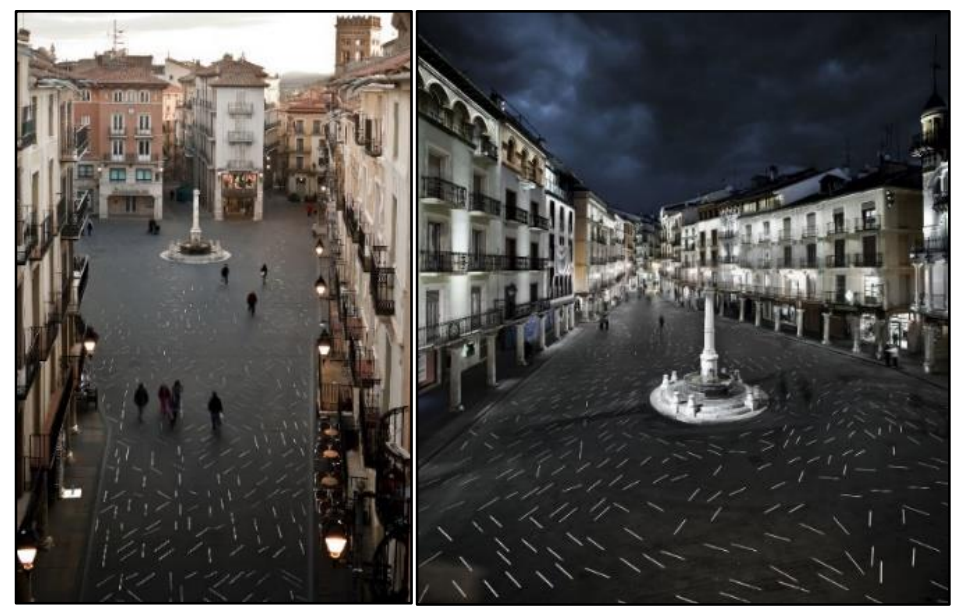

Source: Song, S., 2014

Reducing urban heat islands help people to feel the surroundings cooler and comfortable. Green areas and green roofs absorb the heat and reduce the urban heat islands. Also the planting trees create shading areas and cover the hard surfaces of low reflectivity (Shishegar, N., 2014).

\subsection{Develop Complete Streets}

A Street is complete when it accommodates all kind of transportation. All its users feel comfort when they use cars, bicycle, when they transit or walk. Complete streets should provide service to variety of users such as adults, children and people with disabilities (National Complete Streets Coalition, Complete Streets: A Story of Growing Strength, 2010).

\subsection{Use Cohesive Design Elements}

A sustainable streetscape requires a design which reflects a cohesiveness of its elements such as: materials, colors, properties and details. A cohesive design reflects the design aesthetics and the uniqueness of the street.

\subsection{Promote Security and Safety}

A sustainable streetscape design makes streets safer, it helps minimizing and managing conflicts of walkers and vehicles. Sustainable streetscape energizes pedestrian and encourages them to walk, communicate, share activities and observe the environment (Song, S., 2014).

\subsection{Coordinate Maintenance with Design}

A sustainable street should be maintained to look good all the time. The maintenance of the street is a critical issue for the community. Community should pay attention to the city resources and its involvement in the design process and the maintenance program. The maintenance program should consider many issues such as: graffiti prevention, 
irrigation system, landscape, lighting, sidewalks, street furniture, street sweeping, trash pick-up and tree trimming (Song, S., 2014).

\subsection{Protect and Enhance Historic Character}

Historic elements provide uniqueness and highlights the street's character. Traditional streetscape elements such as paving materials, lighting or other meaningful elements should be retained or re-installed when appropriate. Also new sustainable materials could be consisted to enhance and reinforce the historic character and add design patterns (Song, S., 2014).

\section{SUSTAINABILITY FRAMEWORK}

According to Hass 2012; "Sustainability means maintaining growth or maintaining the organism in a healthy mature state, or, sustainability could mean maintaining a "harmonious balance" between organism and environment" (Nussyba Eraibe, et al., 2015).

The framework of sustainability is based on the preservation and conservation of resources, energy and land-use without depletion of resources. In built environment, sustainability should be achieved in the way of healthy environment, economic growth and better social life. A city could be sustainable when implementing the sustainability practices such as providing: walkable areas, less pollution and less obesity. Mixed-use centers encourage people to walk, communicate, interact, and feel happy. Landscape areas make pedestrians feel comfortable and provide safety and separation of mobility. Using sustainable materials and green techniques reduce the consumption of energy. In other words, preservation of landscape, protection of biodiversity and reduction of energy consumption are the responsibilities for sustainable urbanism (Tezangi, N.R., 2014).

The framework of sustainability consists of the three basic aspects: environmental, social and economic. The environmental aspect enables people to use the environment safely, and in a healthy way such as walking from their homes to different amenities, as well as providing the efficient public transportation. In social terms, sustainable urbanism contains an appropriate set of spaces and buildings with different sizes and types for a mix of community activities; and economically, sustainability is responsible of providing jobs for inhabitants and business opportunities (Tezangi, 2014; Pojani, D. Stead, D., 2015)

\section{PROPOSED SUSTAINABLE STREETSCAPE MATRIX}

Although using streetscape basic principles is an essential approach to reach the sustainability goal when designing a street, but it is not always the only factor. However, evolving community and working on sustainability framework basis makes difference and helps achieving better results. Through the above-mentioned sections, there are basic principles, if properly applied, a sustainable streetscape design can be obtained 
and the street could be "Great". Also the sustainability approach at any level requires social, economic and environmental integration, as mentioned earlier.

In this sense, the study suggests a matrix combining the principles of sustainable streetscape design, and the sustainability approach known at its social, economic and environmental levels. Table (1). In the following part the study will examine this matrix by applying it on the case study "South Grand Boulevard, U.S.A". The case study has been selected as one of four Great Streets Initiative pilot projects in the St. Louis region.

Table (1) Preliminary Proposed Matrix

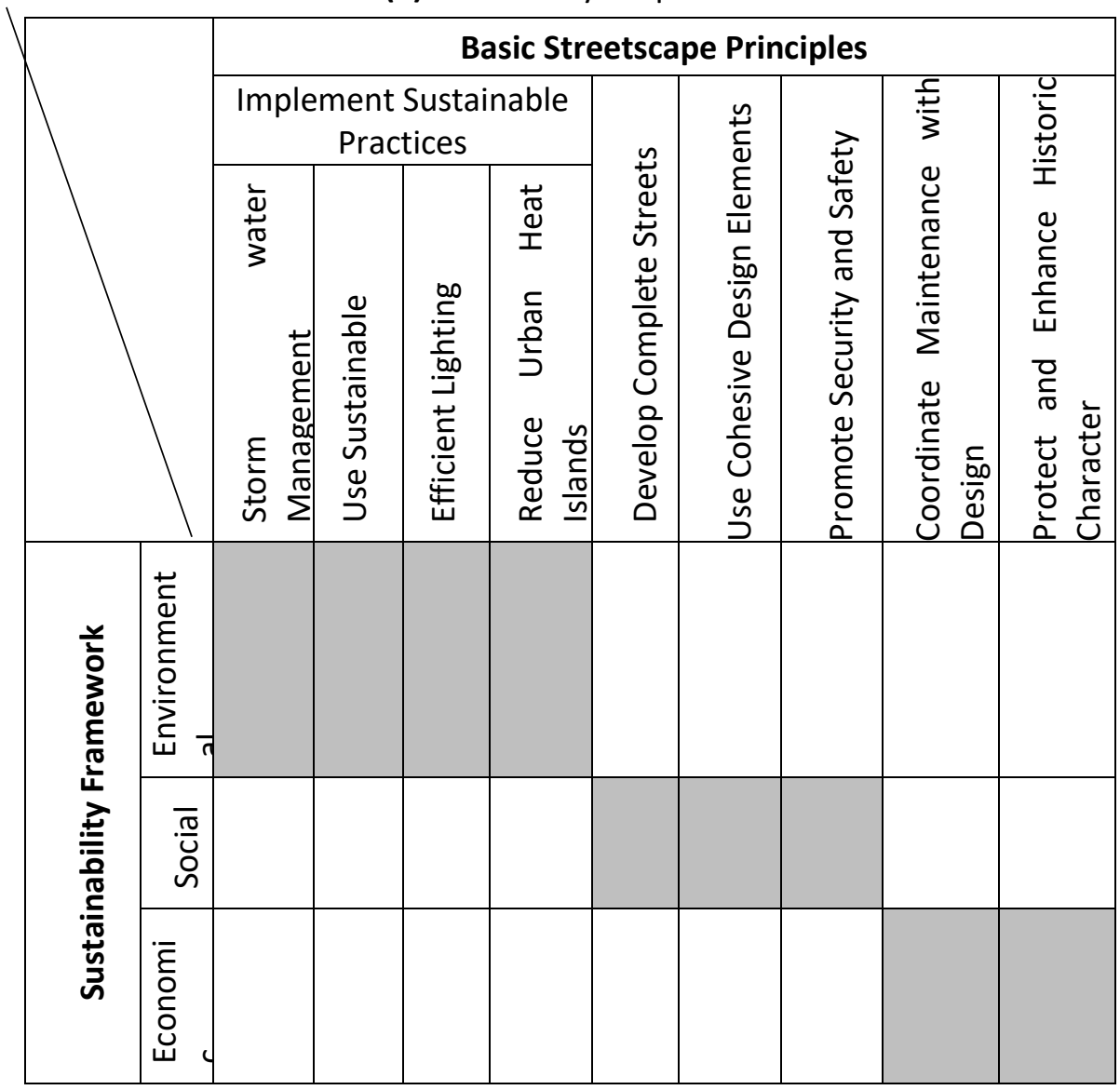

Source: Author

\section{CASE STUDY: South Grand Boulevard, great streets initiative, St. Louis, U.S.A}

The following case study has been selected as it represents a successful transformation of a street to become a great one. This transformation has been based on a sustainable design solutions approach including four metrics: environment, community, economics and arts.

\subsection{Project Background}

South Grand Boulevard is located near Tower Grove Park and the Missouri Botanical Gardens, approximately three miles south of Highway 40/64 and one mile south of 
Interstate 44. Fig (5). This roadway serves as a major North-South corridor for the City. Fig $(6,7,8)$.

Since 2006, East-West Gateway Council of Governments (EWG) has been helping communities in the St. Louis region expand the way they think about streets. They encouraged local leaders and citizens to think and understand how transportation decisions affect the total built environment. It was intended that Great Street in St. Louis become more than a regular street for driving cars. It was planned to emphasize walking as priority, in addition to other modes of travel. EWG recognizes the importance of streets as community resources, in other words; it was intended to transform the street into great community resources. In 2009, South Grand Boulevard was selected as one of four Great Streets Initiative pilot projects in the St. Louis region (South Grand Boulevard Great Streets Initiative report, 2017).

\subsection{Objectives of the project:}

The goal was to change South Grand Boulevard into an "Great Street" while upgrading walkability and secure pedestrians, keeping up traffic stream and improving the appearance and usefulness of the passage and giving chances to proceeded financial advancement. However, what was meant by "Great Streets" here is that they are illustrative of their places, enable individuals to walk easily and securely, add to the economic growth of the City, practically finished streets, give portability, encourage place making and are green (Benfield, K., 2012; Pollak, T.M., 2018). Fig $(9,10)$.

Figure (5) Location South Grand Boulevard, U.S.A

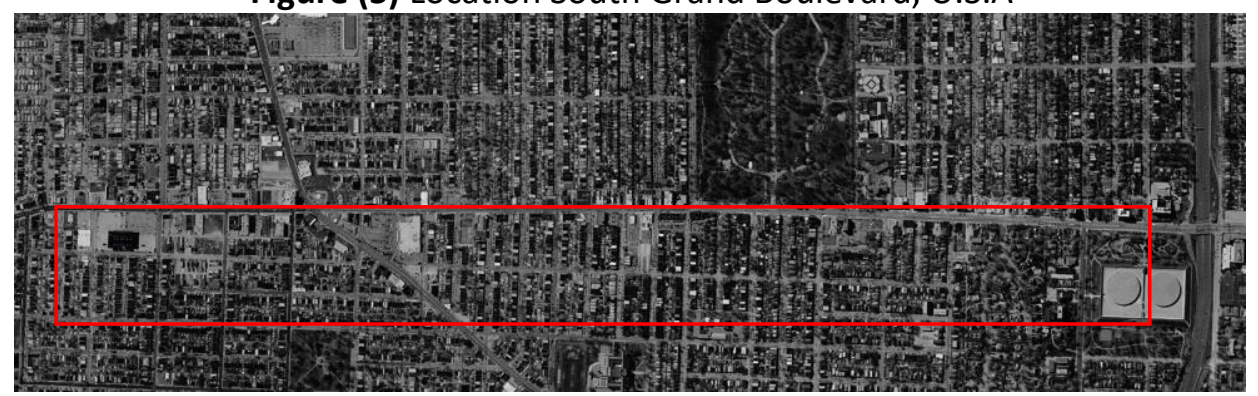

Source: South Grand Boulevard Great Streets Initiative report, 2017 
Figure $(6,7,8)$ Master plan of South Grand Boulevard, U.S.A
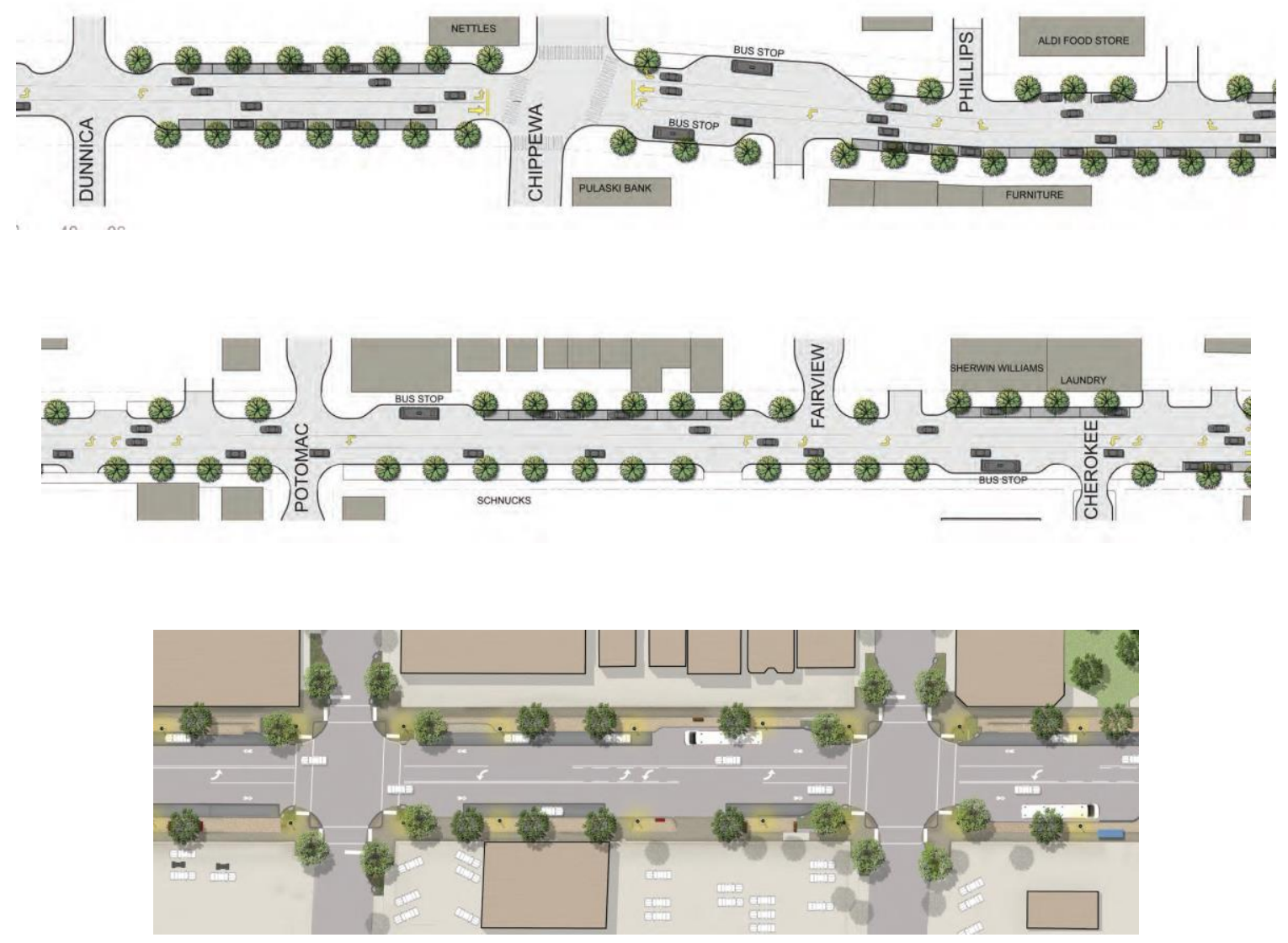

Source: South Grand Boulevard Great Streets Initiative report, 2017

Figure (9) South Grand Boulevard, U.S.A. Perspectives

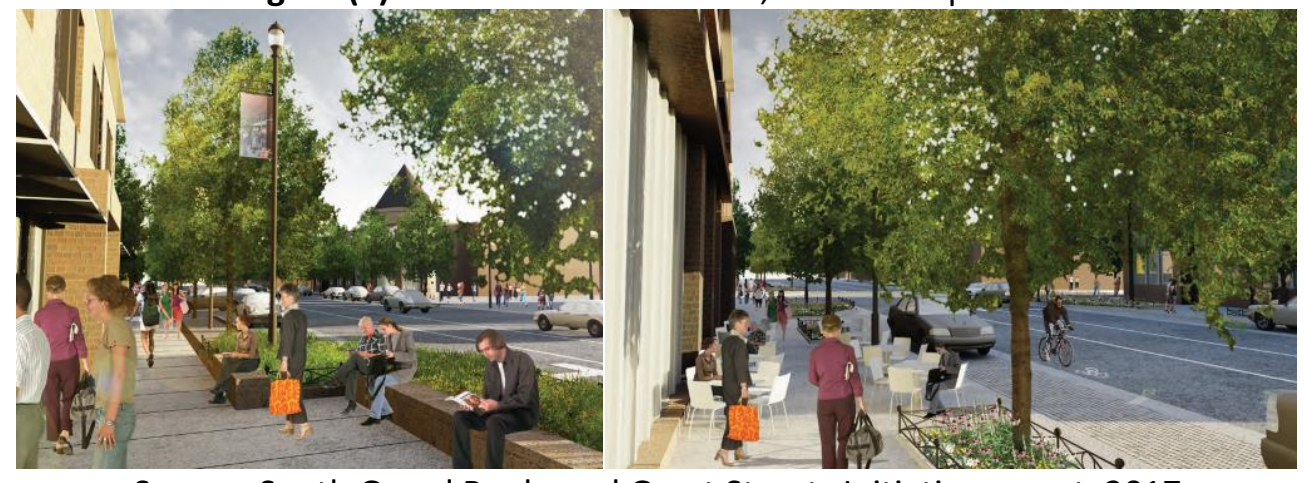

Source: South Grand Boulevard Great Streets Initiative report, 2017 
Figure (10) South Grand Boulevard, U.S.A. Section

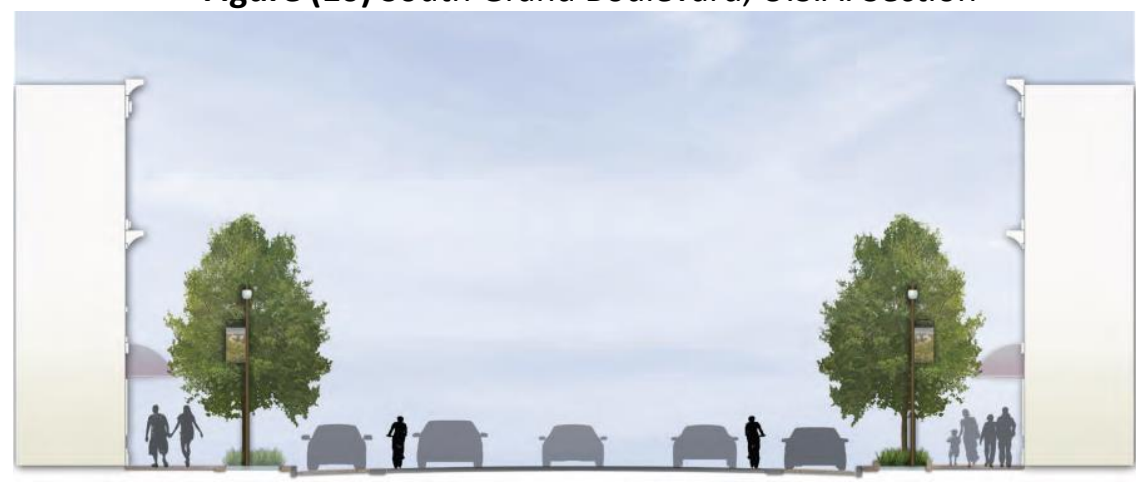

Source: South Grand Boulevard Great Streets Initiative report, 2017

\subsection{Approach to Sustainable Design Solutions}

A process by Design Workshop's DW has been provided to emphasize an intelligent approach to sustainable design solutions that includes four ancient metrics: environment, community, art and economics.

The old metrics represented a discovery-oriented tool and collective vision about the aspirations of the project. They helped develop more comprehensive design solutions by setting goals, and integrating strategies of the four metrics and measurement of results. The metrics resulted in a set of distilled and repetitive goals which will have been applied to design solutions.

South Grand has been redesigned to serve as a "great street" for St. Louis, where the new expectations of the relationship between the community and the transportation appeared in the master plan. The expectations included: improving the safety level, walkability and aesthetics of the street, while setting a new standard for local sustainability and accessibility practices. The South Grand district has been recognized for its strong economic opportunities, community amenities and livability.

\subsection{Application of proposed Matrix}

The following tables represents four metrics proposed by the author consisting of the combination between basic streetscape principles based on the literature review and the sustainability framework including the "public art" aspect based on the analysis of the international case study. The four metrics are: Environmental metrics. Table (2), Social metrics. Table (3), Economic metrics. Table (4), and Public Art metrics. Table (5).

The study implemented the four proposed metrics to analyze the case study, emphasize the intersection zones in order to reach the final matrix that lead to reach a sustainable design solution for great streets.

In this part; the study will apply the proposed matrix in order to emphasize the intersection zones between combining the two main factors: 1 . Streetscape Basic Principles, 2. Sustainability framework. The raw represents the streetscape basic Principles which consists of: storm water management, use of sustainable materials, 
efficient lighting, reducing urban heat islands, develop complete streets and use of cohesive design elements. The column represents the sustainability framework, which consists of the three aspects: environmental, social and economic in addition to another aspect which is "public art" as the study has been adapted the four metrics; environmental, social, economic and arts based on the analysis of the case study. Thus the new set of sustainability framework includes the "public art" aspect which has been added in the case study in order to sustain the city character.

Table (2) Environmental metrics

\begin{tabular}{|c|c|c|c|c|c|c|}
\hline & 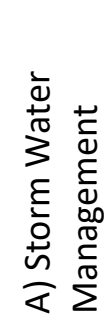 & 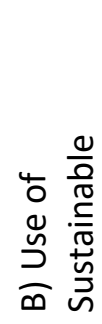 & 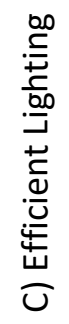 & 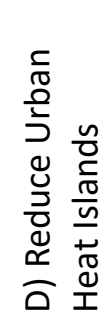 & 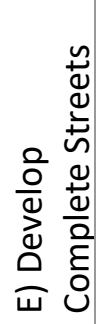 & 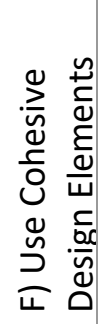 \\
\hline A) Storm water Management & A-A & & & & & \\
\hline B) Landscape Materials & & $B-B$ & & & & \\
\hline C) Waste Management & & C-B & & & & \\
\hline D) Energy and Carbon & & & $\mathrm{D}-\mathrm{C}$ & & & \\
\hline E) Light Pollution Reduction & & & $\mathrm{E}-\mathrm{C}$ & & & \\
\hline F) Heat Island Effect & & & & F-D & & \\
\hline G) Air Quality & & & & G-D & & \\
\hline H) Non-motorized Alternatives Noise Pollution & & & & & H-E & \\
\hline I)Noise Pollution Reduction & & & & & I-E & \\
\hline J) Tree Canopy & & & & & & $J-F$ \\
\hline K) Planting Design & & & & & & $\mathrm{K}-\mathrm{F}$ \\
\hline
\end{tabular}

Source: South Grand Boulevard Great Streets Initiative report, 2017 Edited by Author

A-A: -Storm-water has been directed to rain gardens, utilization of porous pavement. green areas and rain gardens have been maximized.

B-B: Incorporation of local limestone, recycled materials have been used for wall caps and pavers

C-B: Existing concrete, brick and asphalt have been recycled, all the existing materials, sub soil have been used, recycled materials have been used.

D-C: Efficient street lighting and materials with a long life cycle have been used, solar energy has been used, also alternative transportation options. 
E-C: A distribution of light along the corridor has been provided to meet City standards, provide to reduction of light pollution using cut-off fixtures/luminaires, consideration of alternative power sources such as solar in the future.

F-D: Planting trees to shade hardscapes, replace paved areas with planted area and using of hardscape paving materials that are high albedo (reflects less light from light sources such as the sun).

G-D: Reducing heat island effect, using low-volatile paints, running Synchro and Sim traffic emissions analysis, and ensuring proper synchronization of traffic lights.

$\mathrm{H}-\mathrm{E}$ : Increasing the number of bike racks and shared bike lanes. Provide shelters at transit stops.

I-E: Increasing walkability of sidewalks and using traffic- calming techniques to reduce vehicular speed

J-F: Increasing of the quantity of trees and the size of the canopy and replacing the existing street trees with healthy species.

K-F: Choosing good plants for street and reusing of good existing sub-soils.

Table (3) Social metrics

\begin{tabular}{|c|c|c|c|c|}
\hline & 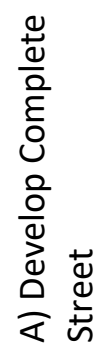 & 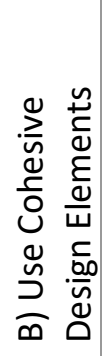 & 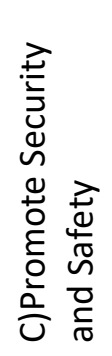 & 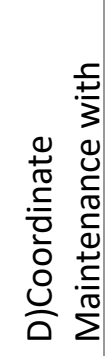 \\
\hline A) Mobility & A-A & & & \\
\hline B) Community Interaction & & B-B & & \\
\hline C)Arts, Culture and Entertainment & & C-B & & \\
\hline D)Emergency Services & & & $\mathrm{D}-\mathrm{C}$ & \\
\hline E) Historic Designation & & & & E-D \\
\hline
\end{tabular}

Source: South Grand Boulevard Great Streets Initiative report, 2017 Edited by Author

A-A: Provide strips for crosswalk, check inclines with distinguishable alerts and signalization, and available parking spots.

$B-B$ : Increase the open spaces for gathering and provide benches for seating

C-B: Engage local artists in the design street and integrate art into street materials and furniture. Invite community leader in the arts to contribute as a member of the design team. Also a sort of signage is beneficial for advertising community events. 
D-C: Ensuring that the emergency access is working and maintained, reduce traffic speeds, increase sidewalk widths, provide improved lighting, provide longer crosswalk signals, provide shorter crosswalk distances, provide accessible pedestrian signals and technologies for assisting special populations (tactile, audible, visual).

E-D: Understanding the history of the place and preserving the historical buildings and services.

Table (4) Economic metrics

\begin{tabular}{l|l}
\hline $\begin{array}{l}\text { A) Supply and } \\
\text { Demand - Retail }\end{array}$ & Filing the empty spaces in the built fabric and in the store front. \\
\hline B) Employment & Encouraging of new jobs in the community \\
\hline
\end{tabular}

Source: South Grand Boulevard Great Streets Initiative report, 2017 Edited by Author

Table (5) Public Art metrics

\begin{tabular}{|c|c|}
\hline & A) Protect and Enhance Historic Character \\
\hline $\begin{array}{l}\text { A) } \\
\text { Identity/Character }\end{array}$ & $\begin{array}{l}\text { Coordination of the design, chosen materials and the elements of the } \\
\text { site to fit in the context and comply with the site's history. }\end{array}$ \\
\hline $\begin{array}{l}\text { B) Functional } \\
\text { Aesthetics }\end{array}$ & Integration of art into the streetscape through its design elements. \\
\hline $\begin{array}{l}\text { C)Collaboration with } \\
\text { Artists }\end{array}$ & $\begin{array}{l}\text { Engagement and encouragement of artists to involve in the creation of } \\
\text { the streetscape design. }\end{array}$ \\
\hline D)Public Art & $\begin{array}{l}\text { To make sure that the public art has a percentage in the construction } \\
\text { budget and identify local sources to fund the art program. }\end{array}$ \\
\hline E) Seasonality & $\begin{array}{l}\text { Using of durable elements that are appropriate for the climate of the } \\
\text { street. }\end{array}$ \\
\hline
\end{tabular}

Source: South Grand Boulevard Great Streets Initiative report, 2017 Edited by Author

\section{DISCUSSION}

The case study has introduced the transformation of South Grand Boulevard into an "Great Street" that has been based on a sustainable design solutions approach including four metrics: environment, community, economics and arts. The sustainable design solutions were based on involving the community in the analysis process, presentation of problems, suggested solutions and the development of general objectives of design. According to the proposed metrics; it is clear that the "public art" aspect represents an important aspect to sustain the city character. Also the "economic" aspect of sustainability approach does not intersect with any factor of basic streetscape principles; which means that it is not covered by these principles but it represents an essential aspect of Sustainability approach.

Based on the above, it is clear to the study that it is possible to combine between: 1 . Streetscape Basic Principles, 2. Sustainability framework in one matrix with the emphasis on the inclusion of the "Public Art" factor. Table (6). Thus it is possible to rely 
on the results of these intersections rather than relying on the set of streetscape basic principles or the set of sustainability approach in a single term.

Table (6) The final proposed Matrix

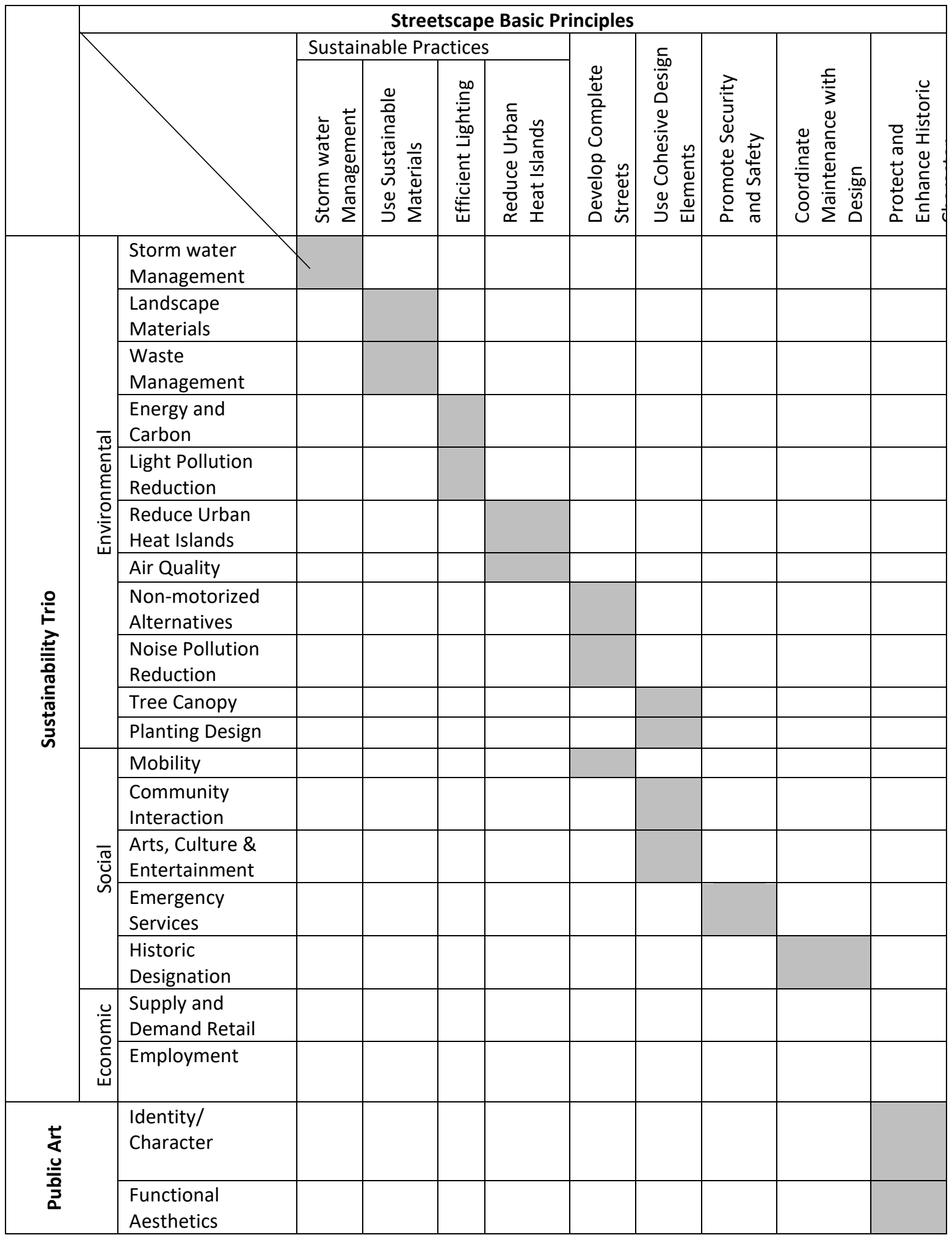




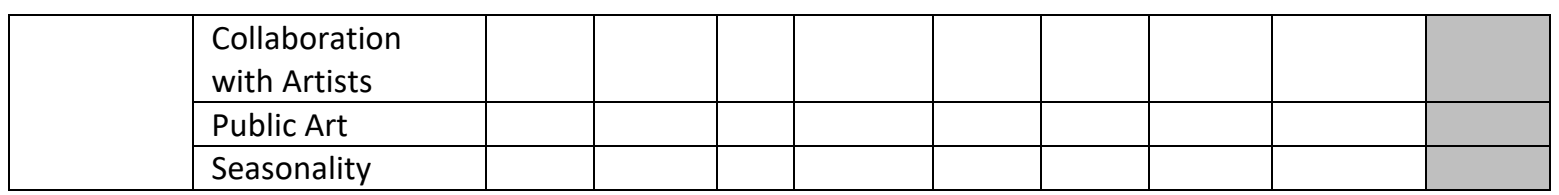

Source: Author

6. APPLICATION OF THE FINAL PROPOSED MATRIX: The Street Renovation Project of AL-ALFY Street, Down Town, Cairo.

\subsection{Location and Historical Background}

Al-Alfy Street derived from Talaat Harb Street, a pedestrian street. After the completion of the work of upgrading and restoration, Al-Alfy Street becomes the first experience to form a union of occupants to follow up the development of the street, and take responsibility continued maintenance, to participate in the executive organs to upgrade it and raise its efficiency and maintain the work done to prevent the waste of public money.

Al-Alfy Street "is located approximately 600 meters from Tahrir Square, it is the largest passage in downtown Cairo. Fig (11). It is 135 meters long and 22 meters wide, linking Orabi Square and Emad El-Din Street. It is the most sophisticated and beautiful streets of the downtown area. Many of the eras on the street facilities, but they still retain their greatness and ancient. It has numerous vintage restaurants and modern cafes on both sides, like Umm Kalthoum Café, Elfalero Sweets, and Al-Alfy Bek Restaurant. This old street and renewed passage dates back to the Mamluk Prince Mohamed Bek Al-Alfy, who fought against the French invasion of Egypt.

Figure (11) Al-Alfy street map

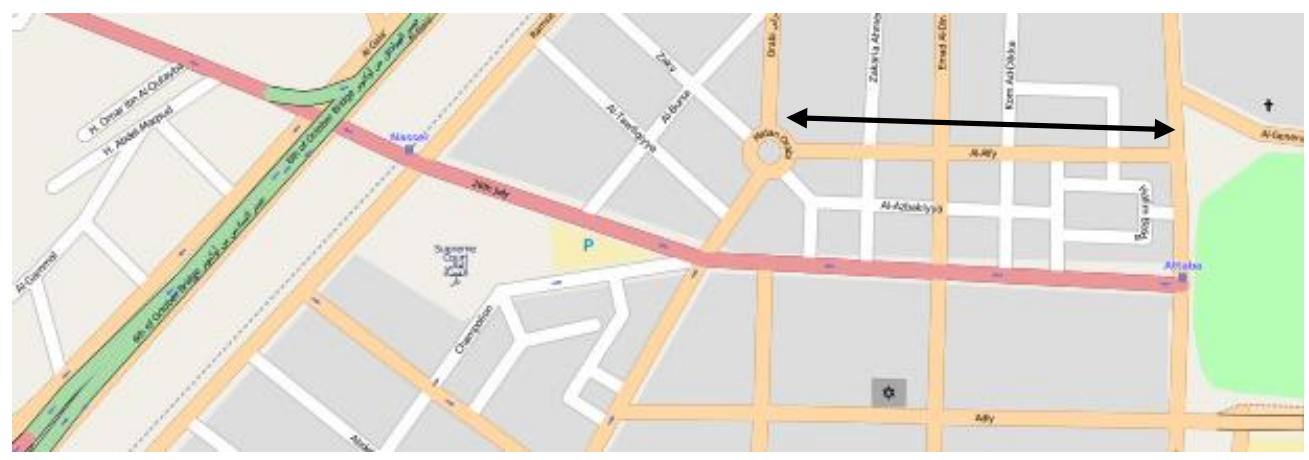

Source: Google map, edited by author

The palace of Al-Alfy, the largest and most beautiful palaces of the Azbakia pool, was among the dozens of palaces surrounding the pool, which were attributed to the Mamluk princes and koaks. Passing by the Azbakia Park and Pool was one of the dreams of the Egyptians at the time. Almost 80 years after the founding of the Great Palace, Khedive Ismail took power and was aware of the dream that his grandfather, Mohamed 
Ali Pasha and his father, Ibrahim Pasha, had left to him. Notable in the field of architecture at the time, and paid great attention to the architecture in the capital, where he hired senior French and Italian architects to achieve what he wanted.

\subsection{The Street Renovation}

In 2014, Al-Alfy Street had the worst reviews since many street vendors were clogging the street's multiple intersections. However, between 2015 and 2017, the street was entirely renovated and redrawn. All street vendors were removed, trees were planted, a new lighting system put in place, and all the former wooden seats were replaced with a novel granite sidewalk. These steps came under a project by Cairo governor. The Department of Heritage Preservation in Cairo Governorate and the National Committee for the Protection of Cairo Heritage started to implement the plan set for the development of Khedive Cairo and to preserve all that has been accomplished before. In coordination with the Cairo Governorate, represented by the Department of Heritage Preservation, with the Union of the Occupants of Al-Alfy Street, places have been designated for shops and separated from places allocated for pedestrian movement, as well as the deployment of flowerpots and seating for citizens to rest on them were designed by a consultant in the Urban Coordination Authority, in addition to Remaintenance and cleaning of the facades of buildings that have been developed and painted before to preserve and re-luster, according to information received from Cairo.

\section{ANALYSIS OF THE PROPOSED MATRIX ON AL-ALFY STREET}

In order to analyze Al-Alfy's street according to the proposed matrix; a regular survey visit to the street has been done by the researcher. There were two visits within the first week of August, and the photos taken are the result of the second visit at 2:30 pm on 8 of August 2019. The visit duration was about 3 hours. The researcher chose this day (Thursday) as it is supposed that the street will be in full capacity and full of users.

The researcher noticed that the transformation of Al-Alfy's street made it walkable and more livable; it improved the interaction between people and considered the history and the identity of the street. The photos; Fig (12 to 19) are recording what the researcher has noticed.

The following analysis is based on the proposed matrix using the four metrics: environmental, social, economic and public arts.

\section{Environmental metrics:}

-Storm water management has been used and local materials for pavement have been utilized. Fig (12).

-Trees have been maximized to reduce urban heat islands and protecting against. Fig (16). 
-Tree canopy has been increased to provide shading, improve air quality, and to increase street value and aesthetics.

-Improving the health of street trees and replacing the existing street trees with healthy species.

-New street lighting units have been added. Fig (14).

\section{Social metrics:}

-The street has been designed as a place that promotes community interaction. Fig (17).

-They Increase the open spaces for gathering and provide benches for seating. Figure (13).

-The traffic speeds have been reduced by closing the street. Fig (19).

-The sidewalk widths have been increased and the lighting units have been improved, also the street provide shorter crosswalk distances and alternative transportation for pedestrians and bikes. Fig (13).

-They improved pedestrian safety and promote security (Kiosk for security reason). Fig (15).

\section{Economic metrics:}

-The street has been designed to create a more coherent district and strengthen its brand. -The street kept its identity and the old shops still there and working.

-New job opportunities were available and encouraged.

\section{Public Art metrics:}

-Coordination of the design, chosen materials and the elements of the site to fit in the context and comply with the site's history were considered.

-Historic Buildings have been maintained and enhanced. Fig (18).

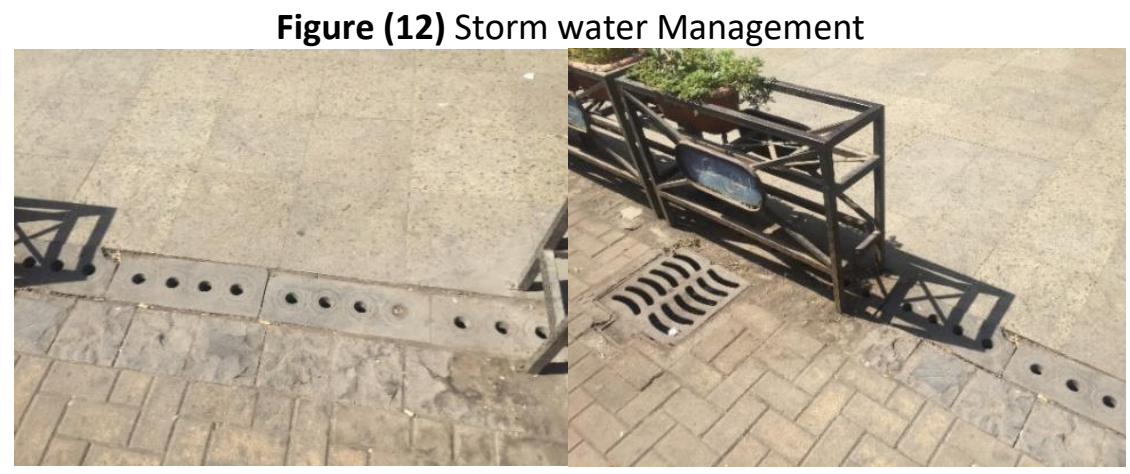

Source: Author 
Figure (13) Incorporation of local extracted and manufactured materials and new benches for seating.

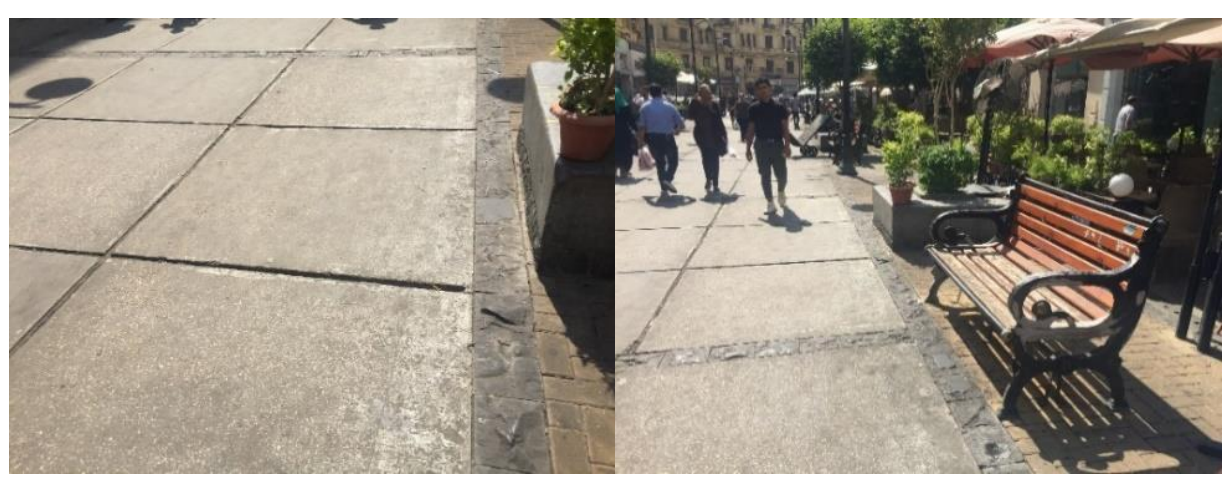

Source: Author

Figure (14) Street lighting

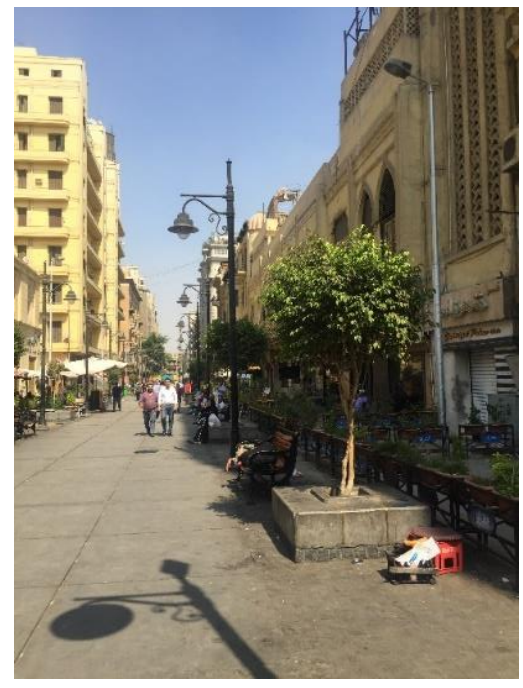

Source: Author

Figure (15) Improving pedestrian safety and Promote Security (Kiosk for security reason)

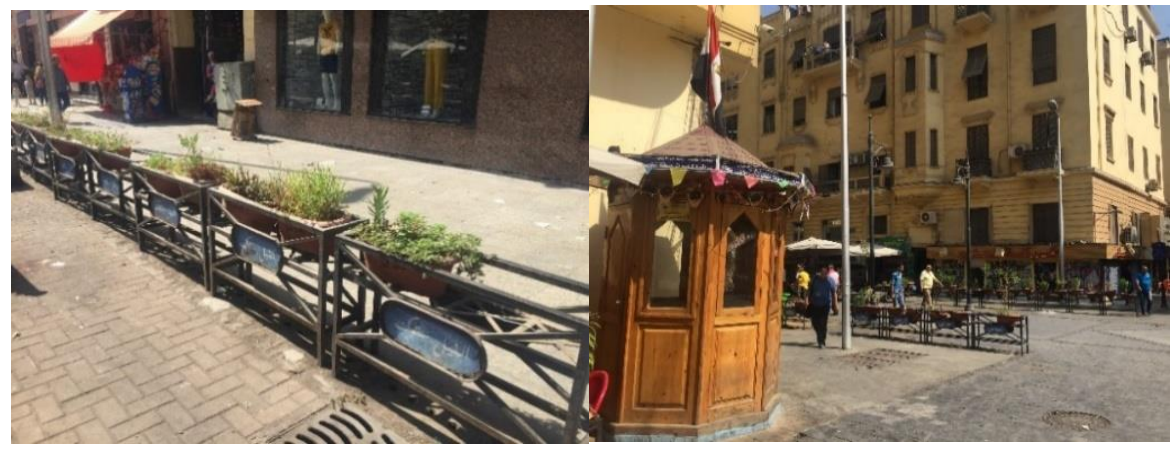

Source: Author 
Figure (16) Planting to reduce Urban Heat Islands

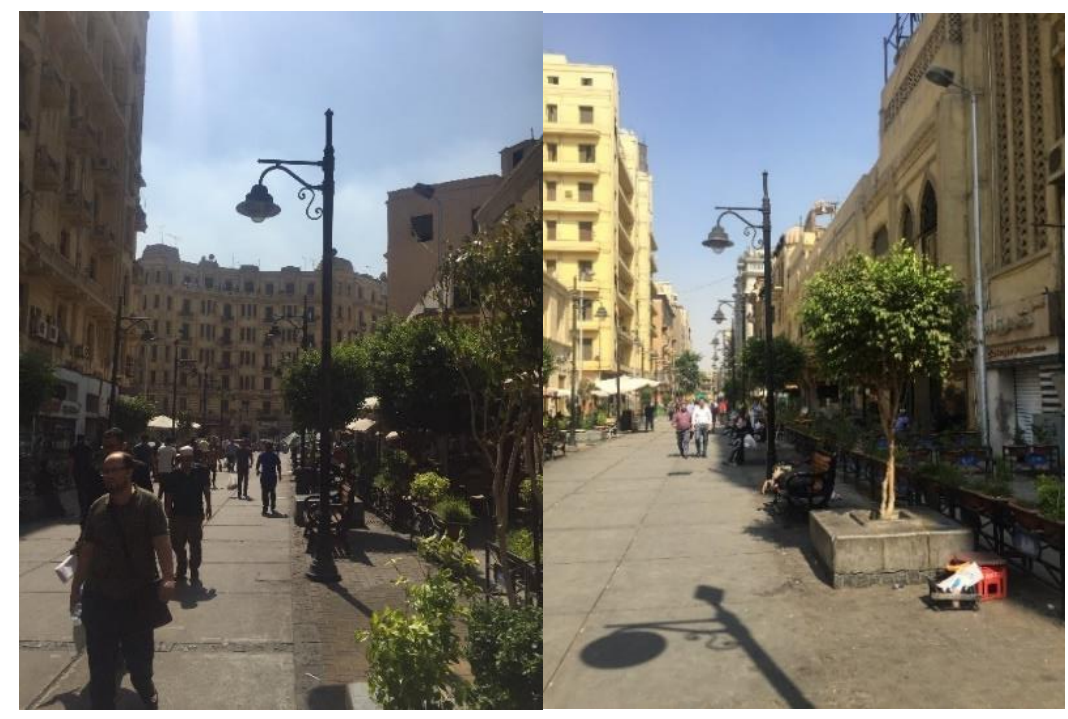

Source: Author

Figure (17) Showing community Interaction

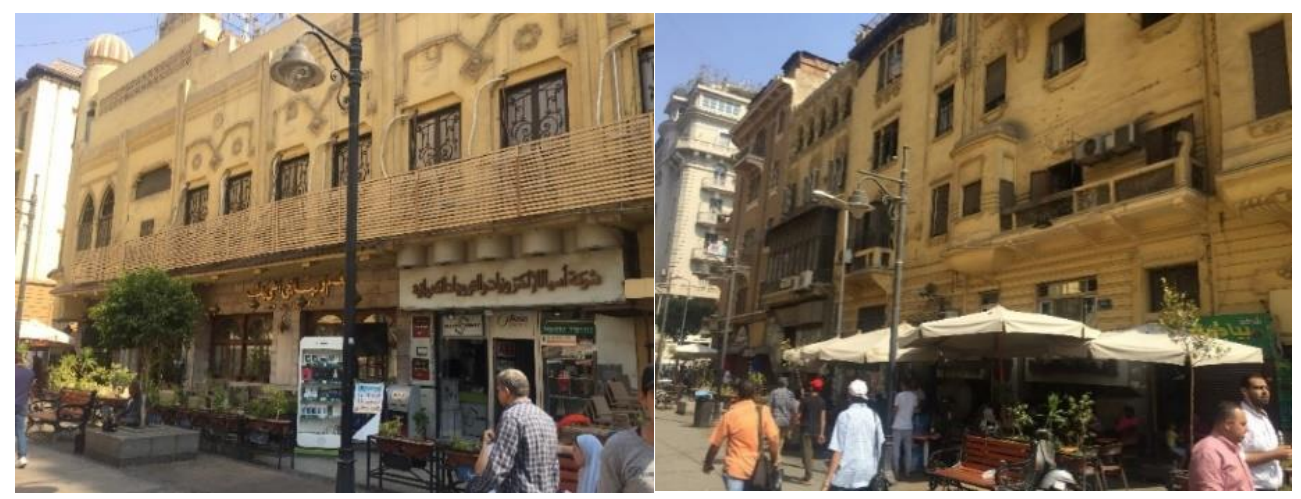

Source: Author

Figure (18) Maintaining and enhancing historic building

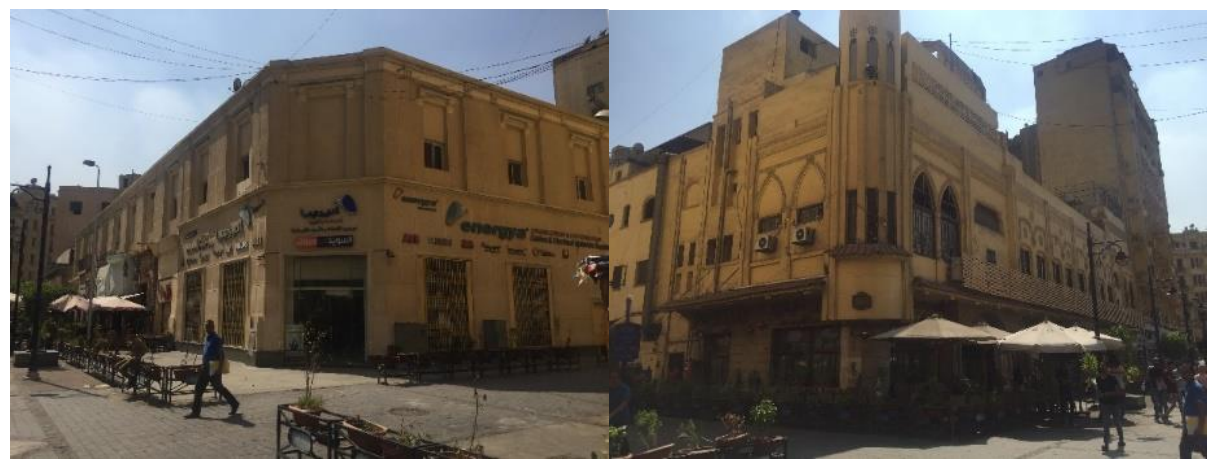

Source: Author 
Figure (19) The street has been closed to allow transportation for pedestrians and bikes

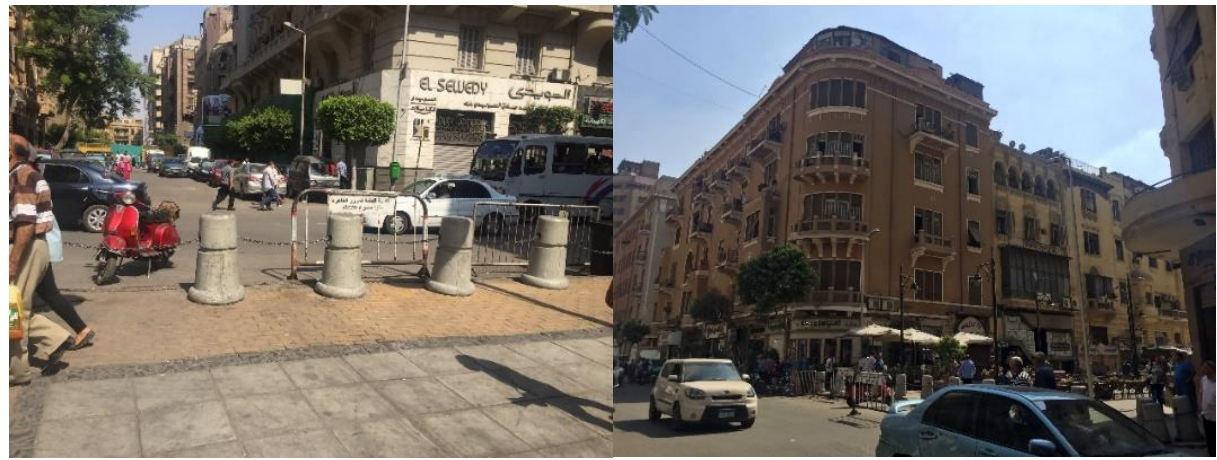

\section{CONCLUSIONS}

Source: Author

The study draws a set of results as follows:

1. Streets are a vital issue in our life in general and it could serve the community in many ways, not only for walking or for transportation uses.

2. In order to design, develop or transform a street to become a great one; Sustainable streetscape practices are not always enough, however adding the sustainable approach to the design process may be more efficient and provide sustainable design solutions.

3. The "Public Art" represents an important factor that could be added to the sustainable approach in addition to the social, environmental and economic aspects and this is in order to sustain the city character.

4. The study concludes the importance of the existence of a number of factors that help to provide sustainable design solutions when designing or transforming a street to become great. In this sense the study proposes the following checklist. Table 7

Table (7) Proposed Checklist

\begin{tabular}{|c|c|c|c|}
\hline & \multicolumn{3}{|c|}{ Environmental Term } \\
\hline \multirow{5}{*}{ 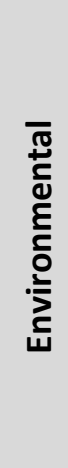 } & $\begin{array}{l}\text { Storm water } \\
\text { Management }\end{array}$ & $\begin{array}{l}\text { Collection of storm water on-site and increasing the quality } \\
\text { of any runoff. }\end{array}$ & 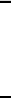 \\
\hline & $\begin{array}{l}\text { Using Sustainable } \\
\text { Landscape Materials }\end{array}$ & $\begin{array}{l}\text { Incorporation of local extracted and manufactured } \\
\text { materials. }\end{array}$ & 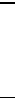 \\
\hline & Waste Management & $\begin{array}{l}\text {-Reducing of the amount of landfill due to construction work } \\
\text {-Supporting recycling programs. }\end{array}$ & 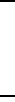 \\
\hline & $\begin{array}{l}\text { Reduce Energy and } \\
\text { Carbon }\end{array}$ & $\begin{array}{l}\text { Using of efficient street lighting to minimize the use of } \\
\text { energy. }\end{array}$ & 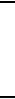 \\
\hline & Reduce Light Pollution & Improving night-sky visibility. & \\
\hline
\end{tabular}




\begin{tabular}{|c|c|c|c|}
\hline & $\begin{array}{l}\text { Reduce Urban Heat } \\
\text { Islands }\end{array}$ & Reducing urban heat island and protecting against. & ) \\
\hline & Air Quality & Improving air quality. & ) \\
\hline & $\begin{array}{l}\text { Non-motorized } \\
\text { Alternatives }\end{array}$ & $\begin{array}{l}\text { Maintaining residents within walking distance to alternative } \\
\text { transportation. }\end{array}$ & ) \\
\hline & $\begin{array}{l}\text { Noise Pollution } \\
\text { Reduction }\end{array}$ & Reducing noise levels. & 1 \\
\hline & Tree Canopy & $\begin{array}{l}\text { Increasing tree canopy to provide savings with regard to } \\
\text { energy, to improve air quality, to intercept storm water } \\
\text { interception and to increase property value and aesthetics. }\end{array}$ & ) \\
\hline & Planting Design & $\begin{array}{l}\text {-Using native plant materials to reduce water usage } \\
\text {-Improving the health of street trees. }\end{array}$ & ) \\
\hline & \multicolumn{3}{|c|}{ Social Term } \\
\hline \multirow{6}{*}{$\frac{\bar{\pi}}{\mathrm{d}}$} & Increasing Mobility & Improving accessibility. & ) \\
\hline & Employment & $\begin{array}{l}\text { Improving alternative transportation for pedestrians, bikes } \\
\text { and transit. }\end{array}$ & ) \\
\hline & Community Interaction & $\begin{array}{l}\text { Designing the street as a place that promotes community } \\
\text { interaction. }\end{array}$ & ) \\
\hline & $\begin{array}{l}\text { Arts, Culture and } \\
\text { Entertainment }\end{array}$ & $\begin{array}{l}\text {-Ensuring that arts, culture and entertainment are accessible } \\
\text { by everyone. } \\
\text {-Encouraging arts to serve as a way to create street identity. }\end{array}$ & ) \\
\hline & $\begin{array}{l}\text { Emergency Services to } \\
\text { Promote Security and } \\
\text { Safety }\end{array}$ & $\begin{array}{l}\text {-Maintaining level of service for emergency vehicles to } \\
\text { access the hospital and victims. } \\
\text {-Improving pedestrian and driver safety. }\end{array}$ & ) \\
\hline & Historic Designation & Maintaining and enhancing historic designation. & ( \\
\hline & \multicolumn{3}{|c|}{ Economic Term } \\
\hline \multirow{3}{*}{ 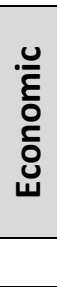 } & $\begin{array}{l}\text { Supply and Demand } \\
\text { Retail }\end{array}$ & $\begin{array}{l}\text { Providing connective tissue to create a more coherent } \\
\text { district and strengthen the brand. }\end{array}$ & ) \\
\hline & Employment & Encouraging new jobs in the community. & ( \\
\hline & \multicolumn{3}{|c|}{ Public Art Term } \\
\hline \multirow{3}{*}{$\frac{\pi}{4}$} & Identity/Character & $\begin{array}{l}\text { Ensuring that the design identifies with the community, the } \\
\text { people and the history of the area. (The art should relate or } \\
\text { contextualize history in a contemporary interpretation). }\end{array}$ & ) \\
\hline & Functional Aesthetics & Balancing art and function & ) \\
\hline & Collaboration with Artists & $\begin{array}{l}\text { Employing local artists to participate and contribute to the } \\
\text { design. }\end{array}$ & 1 \\
\hline
\end{tabular}




\begin{tabular}{|c|c|c|}
\hline Public Art & $\begin{array}{l}\text { Utilizing public art to contribute to the character and } \\
\text { identity. }\end{array}$ & ( \\
\hline Seasonality & $\begin{array}{l}\text { Ensuring that the design is aesthetically pleasing in all } \\
\text { seasons. }\end{array}$ & ) \\
\hline
\end{tabular}

Source: Author

\section{RECOMMENDATIONS}

1. Several researchers can study the possibilities of application of the proposed matrix and then add new factors or remove others in case of proving the uselessness of this factor.

2. Studying the possibilities of improving the checklist in terms of climate and culture in order to be more appropriate to different zones worldwide.

\section{REFERENCES}

Appleyard, D. (1981). Livable streets. London: University of California Press.

Akadiri, P. O. (2012). Design of a Sustainable Building: A Conceptual Framework for Implementing Sustainability in the Building Sector. ISSN 2075-5309, Buildings 2012, 2, 126-152; doi: 10.3390

Benfield, K. (2012). "Defining a Great Street", 6 Sep. 2012. Retrieved from https://www.citylab.com/design/2012/09/defining-great-street/3181/

Berland, A. (2017). The role of trees in urban storm water management. Landscape Urban Plan. 162: 167177. doi: 10.1016/j.landurbplan.2017.02.017

Gehl, J. (2010). Cities for people. Washington: Island Press.

G. S. B. Ganandran, et al. (2014). Cost-Benefit Analysis and Emission Reduction of Energy Efficient Lighting at the University Tenaga Nasional. The Scientific World Journal, Article ID 745894, http://dx.doi.org/10.1155/2014/745894.

Haas, T. (2012). Sustainable Urbanism and Beyond: Rethinking Cities for the Future. Rizzoli International Publications, Inc. ( $1^{\text {st }}$ ed). New York, NY

Jacobs, J. (1961). The Death and Life of Great American Cities. New York: Random House.

Lindfield, M. Steinberg, F. (2012). Urban Development Series: Green Cities. ISBN 978-92-9092-896-6 (Print), 978-92-9092-897-3 (PDF), Asian Development Bank, Philippines. Retrieved https://www.adb.org/sites/default/files/publication/30059/green-cities.pdf.

Nussyba Eiraibe, ALMaha Ahmed AL-Malki, Raffaello Furlan (2015), Exploration of Sustainable Urban Qualities of Al Sadd Area in Doha, American Journal of Sociological Research, Vol. 5 No. 4, pp. 101118. doi: 10.5923/j.sociology.20150504.02

National Complete Streets Coalition, Complete Streets: A Story of Growing Strength. Washington, DC: (2010).

O'Neill, S. J. (2016). New Solutions for Sustainable Storm Water Management in Canada.

Pojani, D. Stead, D. (2015). Sustainable Urban Transport in the Developing World: Beyond Megacities. Sustainability, 7, 7784-7805; doi:10.3390/su7067784.

Pollak T.M. (2018). What Makes a Great Street? Retrieved from https://www.theamericanconservative.com/urbs/what-makes-a-great-street/ 
Shishegar, N. (2014). The Impacts of Green Areas on Mitigating Urban Heat Island Effect: A Review. The International Journal of Environmental Sustainability, Vol. 9, Issue 1, 119-130.

"South Grand Boulevard Great Streets Initiative" Retrieved from https://www.ewgateway.org/wpcontent/uploads/2017/07/GS-SouthGrand-MasterPlan-Complete.pdf

Song, S. (2014). Urban Streetscape Design. Design Media Publishing Limited, ISBN 978-988-12967-2-6. China.

Tezangi, N.R. (2014). Sustainable Urbanism: Analysis of Sustainable Environment Principles in Practical Urban Form. Journal of Engineering and Architecture, Vol. 2, No. 2, pp. 197-205, ISSN: 2334-2986 (Print), 2334-2994 (Online), DOI: 10.15640/jea. v2n2a14. 